\title{
Evaluating the Use of Songs in the Teaching of English as a Foreign Language to Toddlers
}

\author{
Elisavet Nakou \\ (Dip. Harmony, Counterpoint, Fugue, Gr.5 Yamaha Music Foundation, EFL teacher)
}

\begin{abstract}
Listening to songs, as well as singing, is a part of every child's life. A song can not only entertain a child, but it can also be used to teach. The aim of this study is to evaluate the use of songs in the teaching of English as a foreign language to toddlers (2-3 years old). This research was conducted in an English language school in Athens, Greece. The students were children at the age of 2-3, accompanied by their parents. The lessons took place once a week and lasted 45 minutes. The materials used were songs with lyrics written especially for this age group and with the aim of teaching children specific key words. The songs involved making movements according to the lyrics and playing percussion instruments. The role of the teacher and the parents is also highlighted in this study, as their role is vital in the learning process. The study showed that the children took an active part in following the teacher's movements during the songs from the first lesson. At the end of the school year, the children were able to understand the meaning of the key words and move their bodies accordingly. Regarding the development of their speaking skills with respect to the English language, the children found it easier to say onesyllable words in comparison with two-syllable and multi-syllable words. However, it was difficult for the children to sing the songs and there was no speech production in the English language.
\end{abstract}

Keywords: lyrics; movement; parent; routine; teacher 